\title{
Combating SARS-CoV-2: Leveraging microbicidal experiences with other emerging/re-emerging viruses
}

\author{
M. Khalid Ijaz ${ }^{\text {Corresp., } 1,2}$, Syed A. Sattar ${ }^{3}$, Joseph R. Rubino ${ }^{1}$, Raymond W. Nims ${ }^{4}$, Charles P. Gerba ${ }^{5}$ \\ ${ }^{1}$ Global Research \& Development for Lysol and Dettol, Reckitt Benckiser LLC, Montvale, New Jersey, USA \\ 2 Department of Biology, Medgar Evers College of the City University of New York (CUNY), Brooklyn, New York, USA \\ 3 Faculty of Medicine, University of Ottawa, Ottawa, Ontario, Canada \\ 4 RMC Pharmaceutical Solutions, Inc., Longmont, Colorado, USA \\ 5 Water \& Energy Sustainable Technology Center, University of Arizona, Tucson, Arizona, United States \\ Corresponding Author: M. Khalid ljaz \\ Email address: khalid.ijaz@rb.com
}

The emergence of severe acute respiratory syndrome coronavirus 2 (SARS-CoV-2) in Wuhan City, China, late in December 2019 is an example of an emerging zoonotic virus that threatens public health and international travel and commerce. When such a virus emerges, there is often insufficient specific information available on mechanisms of virus dissemination from animal-to-human or from person-to-person, on the level or route of infection transmissibility or of viral release in body secretions/excretions, and on the survival of virus in aerosols or on surfaces. The effectiveness of available virucidal agents and hygiene practices as interventions for disrupting the spread of infection and the associated diseases may not be clear for the emerging virus. In the present perspective, we recommend approaches for infection prevention and control (IPAC) for SARS-CoV-2 and future emerging/re-emerging viruses which can be invoked based on pre-existing data on microbicidal and hygiene effectiveness for related and unrelated enveloped viruses. 
1 Combating SARS-CoV-2: Leveraging microbicidal experiences with 2 other emerging/re-emerging viruses

3

4 M. Khalid Ijaz ${ }^{1,2}$, Syed A. Sattar ${ }^{3}$, Joseph R. Rubino ${ }^{1}$, Raymond W. Nims ${ }^{4}$, \&

5 Charles P. Gerba ${ }^{5}$

6

$7 \quad{ }^{1}$ Global Research \& Development for Lysol and Dettol, Reckitt Benckiser LLC, Montvale, New 8 Jersey, USA

$9{ }^{2}$ Department of Biology, Medgar Evers College of the City University of New York (CUNY), 10 Brooklyn, New York, USA

$11{ }^{3}$ Faculty of Medicine, University of Ottawa, Ottawa, Ontario, Canada

$12 \quad{ }^{4}$ RMC Pharmaceutical Solutions, Inc., Longmont, Colorado, USA

$13 \quad{ }^{5}$ Water \& Energy Sustainable Technology Center, University of Arizona, Tucson, Arizona, USA 14

Corresponding author:

Address correspondence to Dr. M. Khalid Ijaz, Director of Scientific Affairs, Global Research \& Development for Lysol and Dettol, Reckitt Benckiser LLC, One Phillips Parkway, Montvale, NJ 07645.

M. Khalid Ijaz, khalid.ijaz@,rb.com 


\section{ABSTRACT}

The emergence of severe acute respiratory syndrome coronavirus 2 (SARS-CoV-2) in Wuhan City, China, late in December 2019 is an example of an emerging zoonotic virus that threatens public health and international travel and commerce. When such a virus emerges, there is often insufficient specific information available on mechanisms of virus dissemination from animal-tohuman or from person-to-person, on the level or route of infection transmissibility or of viral release in body secretions/excretions, and on the survival of virus in aerosols or on surfaces. The effectiveness of available virucidal agents and hygiene practices as interventions for disrupting the spread of infection and the associated diseases may not be clear for the emerging virus. In the present review, we suggest that approaches for infection prevention and control (IPAC) for SARS-CoV-2 and future emerging/re-emerging viruses can be invoked based on pre-existing data on microbicidal and hygiene effectiveness for related and unrelated enveloped viruses.

Keywords Ebola virus, Enterovirus D68, Hantaan virus; Lassa virus, Microbicides, MERS-CoV, Nipah virus, SARS-CoV, SARS-CoV-2, SFTSV

\section{INTRODUCTION}

Late in December 2019, cases of pneumonia began appearing in Wuhan City, Hubei Province, China. By early January 2020, these cases were attributed to a novel coronavirus that was temporarily referred to as 2019 Novel Coronavirus (2019-nCoV) (WHO, 2020a). This member of the Coronaviridae family was subsequently named SARS-CoV-2 (Gorbalenya et al., 2020). As of August 11, 2020 (WHO, 2020c), there have been over 19,936,210 confirmed cases globally, with 732,499 deaths (case mortality rate of $3.7 \%$ ). This emerging virus, and the associated disease (COVID-19), have not only impacted public health, but also international commerce and travel. As with the Middle East respiratory syndrome coronavirus (MERS-CoV) that emerged in Saudi Arabia in 2012 and the severe acute respiratory syndrome coronavirus (SARS-CoV) that emerged in China in early 2003, SARS-CoV-2 is considered a zoonosis, with bats suspected as the primary host species (Table 1) (Zhu et al., 2020; Li et al., 2020).

The Coronaviridae is just one of several families of enveloped viruses that have emerged/reemerged in recent years (Table 1) (Zhan et al., 2017; Ang et al., 2018; Brocato and Hooper, 2019; Laenen et al., 2019; Viral Hemorrhagic Fever Consortium, 2019). While the list of viruses in Table 1 is not intended to be comprehensive, it contains most of the virus families attributed to the World Health Organization (WHO) current list of disease priorities needing urgent R\&D attention (WHO, 2015) (i.e., MERS and SARS [Coronaviridae], Crimean Congo hemorrhagic fever (Nairoviridae), Rift Valley fever [Phenuiviridae], Ebola virus disease and Marburg virus disease [Filoviridae], Nipah and Hendra virus disease [Paramyxoviridae], and Lassa fever [Arenaviridae]).

To our knowledge, no one has systematically compared the characteristics of the viruses causing the diseases in the WHO current list of disease priorities needing urgent R\&D attention ( $W H O, 2015)$. There may be common characteristics that may favor sustained transmissibility or mortality and could inform IPAC activities. This review is intended to aid the IPAC community in arriving at strategies for dealing with SARS-CoV-2, as well as future emerging/re-emerging viruses, by evaluating relevant characteristics of these viruses of concern. In particular, it is our 
67 hope that this information may be leveraged to effectively mitigate the health risks associated 68 with SARS-CoV-2 and its associated disease (COVID-19), as well as with future emerging/re69 emerging enveloped viruses.

The emerging/re-emerging viruses shown in Table 1, with the exception of enterovirus D68, each are relatively large, enveloped, zoonotic viruses with single-stranded RNA genomes. Enterovirus D68 (EV-D68), a small non-enveloped virus of the Picornaviridae family, is an example of a re-emerging virus from that family. While EV-D68 may also be zoonotic (Bailey et al., 2018; Fieldhouse et al., 2018), a reservoir species has yet to be identified for that virus.

Aside from the characteristics described in Table 1, what other commonalities exist for these emerging/re-emerging zoonotic viruses? Can we use these commonalities as the basis for proposing approaches for IPAC? In the remainder of this review, we examine various aspects of the emerging/re-emerging viruses that may be important in formulating approaches for IPAC, namely transmissibility, infectivity, viral shedding, environmental survival, and expectations regarding microbicidal efficacy for targeted hygiene practices. Our hypothesis is that, when dealing with emerging enveloped viruses, knowledge of the susceptibility of one enveloped virus to microbicides which disrupt the lipid envelope should enable one to predict which microbicides should prove efficacious for other enveloped viruses, including emerging/re-emerging viruses.

\section{SURVEY METHODOLOGY}

This literature review focused upon the WHO list of diseases of concern $(\mathrm{WHO}, 2015)$ and our search of the literature pertaining to the various virus characteristics considered in Tables 1-3. As such, the PubMed and Google Scholar search terms included the virus names themselves as well as terms encompassing the topics addressed in the tables. These therefore included coronaviruses, Lassa virus, SFTSV, Hantaan virus, MERS-CoV, SARS-CoV, SARS-CoV-2, Ebola virus, influenza H5N1, Nipah virus, EV-D68, particle size, reservoir species, tissue tropism, mode of transmission, transmissibility, virus shedding, minimal infectious dose, infectious dose ${ }_{50}$, mortality, survival on surfaces, persistence on surfaces, stability on surfaces, survival in aerosols, persistence in aerosols, stability in aerosols, microbicidal efficacy, virucidal efficacy, disinfectant efficacy, antiseptic efficacy, emerging/re-emerging enveloped viruses, UVC susceptibility, zoonoses, and personal hygiene for SARS-CoV-2. Active search of the literature concluded as of July 31, 2020. No exclusion criteria were used. This was not intended to represent a comprehensive review of the literature addressing all of the topics covered. Rather, it represents a compilation, by the authors, of the salient information regarding the set of emerging/re-emerging viruses under evaluation that, hopefully, will enable the reader to consider possible commonalities that inform IPAC. Our bias was toward information on the viruses causing the WHO diseases of concern and SARS-CoV-2, especially, in order to render the review of most potential utility and interest to the IPAC community. This, necessarily, resulted in our paying greatest attention to articles primarily from the past 15 years and to 2020 research and review articles pertaining to SARS-CoV-2 topics.

\section{TRANSMISSIBILITY OF EMERGING/RE-EMERGING VIRUSES}

According to several authors (Geoghegan et al., 2016; Walker et al., 2018; Munster et al., 2020), sustained person-to-person transmission of viruses is favored by certain viral characteristics, including lack of a lipid envelope, small particle size, limited genomic segmentation, and low mortality of the associated disease. Tropism of the virus for the liver, central nervous system 
110 (CNS), or the respiratory tract, and lack of vector-borne transmission also appear to favor 111 sustained person-to-person transmission (Geoghegan et al., 2016; Walker et al., 2018). On the 112 other hand, possession of an RNA vs. a DNA genome was not found to contribute to the 113 likelihood of such sustained transmission (Geoghegan et al., 2016; Walker et al., 2018).

114 It is of interest that many of the viral characteristics mentioned above that are considered 115 predictive of sustained person-to-person transmissibility are not shared by the viruses associated with the WHO diseases of concern. Namely, all of the emerging/re-emerging diseases mentioned in the WHO list ( $W H O, 2015)$ involve relatively large enveloped viruses with ssRNA genomes, many of which are segmented. Of the emerging/re-emerging viruses listed in Table 1, only EVD68 is a small, non-enveloped virus. In addition, many of the WHO viruses of concern exhibit relatively high human mortality (Tables 1 and 2). It should be noted that the mortality values found in the literature for these emerging/re-emerging viruses represent case mortality rates (i.e., number of deaths per number of confirmed cases), not true mortality rates (i.e., numbers of death per number of infected persons). True mortality rates for these viruses are not known, though are likely to be lower than the case mortality rates displayed, as all asymptomatic cases are not included in the case mortality calculation. Certain predictive factors (Geoghegan et al., 2016; Walker et al., 2018; Munster et al., 2020) that do seem to be shared by the emerging/re-emerging viruses in the list in Table 1 include tropism for the respiratory tract or the CNS, and lack of vector-borne transmission. While most enteroviruses are less susceptible to acid and are disseminated by the fecal-oral route, EV-D68 is acid-labile and has a lower temperature optimum, reflecting its tropism for the upper respiratory tract rather than the gastrointestinal tract (i.e., EV-D68 acts more like a rhinovirus than an enterovirus) (Sun et al., 2019).

It is unknown if sustained person-to-person transmissibility necessarily equates to a high level of concern for an emergent zoonotic virus. For instance, there appears to be no evidence that Hendra virus (another zoonotic enveloped virus) has shown person-to-person transmission (Paterson et al., 2011), yet this virus is similar to Nipah virus in many respects and is of concern, due its high case mortality rate in humans.

As mentioned in Table 2, the most common modes of transmission for the emerging/reemerging viruses discussed in this review are contact with infected bodily secretions/excretions and contaminated fomites, especially high-touch environmental surfaces (HITES), and inhalation of respiratory droplets/aerosols containing infectious virus (Fig. 1). The intermediacy of hands in transmission through contact is emphasized in Fig. 1.

The animal-to-human and person-to-person transmission of SARS-CoV-2 and associated COVID-19 disease appears to occur in a manner similar to that described for MERS-CoV and SARS-CoV. That is, the transmission of SARS-CoV-2 (Fig. 1) primarily involves direct inhalation of large respiratory droplets or inhalation of small airborne droplets (Morawska et al., 2020; Patel et al., 2020; WHO, 2020) leading predominantly to respiratory tract infections. Secondary (indirect) transmission of SARS-CoV-2 may also occur through contamination of HITES by droplets and respiratory aerosols or other patient's bodily fluids (bronchoalveolar fluid, sputum, mucus, blood, lacrimal fluid, semen, urine, or feces) (Morawska et al., 2020; Patel et al., 2020; WHO, 2020; Wang et al., 2020). Evidence of the role for the latter transmission pathway comes from experimental transmission studies in animal models (Sia et al., 2020) and by the results of investigations on the contamination of HITES with SARS-CoV-2 RNA in healthcare settings (Jiang et al., 2020; Ong et al., 2020; Patel et al., 2020; Ye et al., 2020). 
154

155

156

157

158

159

160

161

162

163

164

165

166

167

168

169

170

171

172

173

174

175

176

177

178

179

180

181

182

183

184

185

186

187

188

189

190

191

192

193

194

195

196

\section{INFECTIVITY AND VIRUS SHEDDING OF EMERGING/RE-EMERGING VIRUSES}

The infectivity of a virus refers to its ability to initiate infection of a host cell with production of viral progeny. The infectious dose ${ }_{50}\left(\mathrm{ID}_{50}\right)$ is the smallest number of infectious virus particles that will lead to infection of 50\% of an exposed population (Westwood and Sattar, 1974), and is dependent on a number of factors, such as the species, age, or race of the host, the receptor, immune and nutritional status of the host or host tissues, and the portal of entry of the virus. In the case of most viruses, only a percentage of those infected actually develop clinical illness (Haas et al., 2014). Those who remain asymptomatic represent subclinical cases of the infection in whom the virus may still replicate and be released into the environment. This has, in fact, been reported to occur in the case of SARS-CoV-2 (Furukawa et al., 2020; Gandhi et al., 2020). IPAC may be difficult in the face of such silent disseminators (virus carriers/shedders). Exposure to as low as one infectious viral particle has a probability of causing an infection leading to disease, although that probability varies from virus to virus (Yezli and Otter, 2011). Typically, infectious doses are empirically derived and reported in units of $50 \%$ infective dose $\left(\right.$ ID $\left._{50}\right)$ values that reflect the doses capable of infecting half of the subjects exposed. As prospective studies in humans of highly pathogenic viruses with potentially fatal outcomes (such as SARS-CoV-2) cannot ethically be performed, very limited data exist on the infectivity of the emerging/reemerging viruses in Table 1. Where studies have been performed using animals, extrapolations of such data to humans must be made with caution.

The estimates that have been reported for viruses listed in Tables 1 and 2 are discussed below, acknowledging the unavoidable variability in literature with regard to such assessments of infectivity. It has been stated that 1-10 infectious aerosolized Ebola virus particles can cause an infection in humans (Franz et al., 1997; Bibby et al., 2017). A similar range has been reported for Lassa virus (Cieslak et al., 2019). Influenza virus infectivity values specific to the H5N1 and H7N9 strains are not available, but estimates of 100 to 1000 infectious viral particles have been reported (Yezli and Otter, 2011; Cieslak et al., 2019). The human infective dose for SARS-CoV has been estimated at 16 to 160 plaque-forming units (Watanabe et al., 2010). Data on the human infectious doses for MERS-CoV, severe fever with thrombocytopenia syndrome virus (SFTSV), Nipah virus, EV-D68, and SARS-CoV-2 have not been reported. Until such data become available, it should be assumed that these emerging/re-emerging viruses, including SARS-CoV-2, have relatively low ID $_{50}$ values.

Once infected with one of these emerging/re-emerging viruses, during the prodromal period before actual appearance of symptoms, as well as once symptoms appear, the infected individual may become a shedder of infectious particles, as mentioned above. The extent to which virus shedding might lead to dissemination of the associated disease depends upon a number of factors, including the amount of virus released (shed), the infectivity of the virus within the released matrix (droplets/aerosols, fecal/diarrheal discharge, and other excretions, including respiratory secretions), and the survival of the released viruses within such matrices once dried on HITES. Extent of virus shedding, unfortunately, is commonly measured through detection of genomic material (e.g., Otter et al., 2011; Yezli and Otter, 2011; Hassan et al., 2018; Killerby et al., 2020; Santarpia et al., 2020), rather than through use of cell-based infectivity assays, so there are only limited data available on infectious SARS-CoV-2 viral shedding (Francis et al., 2020; Widders et al., 2020; Santarpia et al., 2020a,b). 
As displayed in Fig. 1, transmission of respiratory infections commonly involves the intermediacy of the hand. The same can be said about gastrointestinal infections (i.e., through the fecal-oral route). The coronaviruses SARS-CoV, MERS-CoV, and SARS-CoV-2 have been reported (Otter et al., 2011; Zhang et al., 2020) to be shed from patients both within respiratory and gastrointestinal secretions/excretions, therefore contaminated HITES and large and small respiratory droplets/aerosols may potentially play an important role in dissemination of SARSCoV-2 (Morawska et al., 2020), in many cases through the intermediacy of hands (Guo et al., 2020).

\section{VIRAL SURVIVAL ON ENVIRONMENTAL SURFACES AND IN AIR}

Knowledge of the transmissibility and infectivity of emerging/re-emerging viruses enables one to assess the risk of spread of a viral disease in the case that infectious virus is shed from an infected individual and is deposited on environmental surfaces/fomites or in droplets/aerosols. Another important factor to consider when assessing risk is the survival (i.e., the continued infectivity) of these viruses on the environmental surfaces/fomites or in air in the form of droplets/aerosols.

There is much more information addressing survival of infectious viruses on environmental surfaces than in aerosols. The data that are available address a number of environmental factors of relevance (Otter et al., 2011), including the types and porosities of the surfaces, the matrices in which the viruses have been suspended prior to being deposited onto the surfaces, the temperature and relative humidity $(\mathrm{RH})$, and methods used for measuring survival (e.g., $\log _{10}$ reduction in infectivity per unit time, infectivity half-life, infectious titer after a measured duration, etc.). For Table 3, the results that have been displayed focus on room temperature (ambient) conditions at relatively low and medium RH. Table 3 should not, therefore, be considered to represent a comprehensive review of literature for survival of these viruses on surfaces. For a more systematic review of coronavirus survival on environmental surfaces under various conditions, see the reviews by Otter et al. (2011), Kampf et al. (2020), Ren et al. (2020), Castaño et al. (2020), and Aboubakr et al. (2020). For certain viruses (e.g., SFTSV), survival data are not yet available, so data for surrogate viruses from the same or similar families are shown in Table 3.

Infectious virus survival (persistence) of SARS-CoV-2 on experimentally contaminated protoypic-HITES and in air has recently been reported by van Doremalen et al. (2020) and on surfaces by Chin et al. (2020), Pastorino et al. (2020), Harbourt et al. (2020), and Kasloff et al. (2020). SARS-CoV-2 was found to remain infectious in aerosols for at least the 3-hour period studied by van Doremalen et al. (2020). Not all of these data are displayed in Table 3. The survival half-life estimated based on the limited period of observation of that study was 68 minutes. In experiments conducted with $\mathrm{HCoV}-229 \mathrm{E}$ over a 6-day observation period, the survival half-life was found to depend on relative humidity $(\mathrm{RH})$ and temperature (Ijaz et al., 1985). At $20^{\circ} \mathrm{C}$, the half-life values observed were 3.3 hours $(\sim 80 \% \mathrm{RH}), 67$ hours $(50 \% \mathrm{RH})$, and 27 hours $(30 \% \mathrm{RH})$. A different pattern of results was obtained at low temperature $\left(6{ }^{\circ} \mathrm{C}\right)$ and high $\mathrm{RH}(\sim 80 \sim)$, with the half-life increasing to 86 hours, nearly 30 times that found at $20^{\circ} \mathrm{C}$ and high $\mathrm{RH}$. The pronounced stabilizing effect of low temperature on the survival of $\mathrm{HCoV}-$ $229 \mathrm{E}$ at high $\mathrm{RH}$ indicates that the role of the environment on the survival of coronaviruses in air may be more complex and significant than previously thought (Ijaz et al., 1985). This likely is the case for SARS-CoV-2 as well. The survival of SARS-CoV-2 on prototypic HITES has been 
241 investigated, and survival of the virus has been reported for up to 24 hours on cardboard and 2 to

2424 days on plastic and stainless steel surfaces. Survival in the presence of an organic load was generally longer than survival in the absence of such a load (Chin et al., 2020; van Doremalen et al., 2020; Kasloff et al., 2020; Pastorino et al., 2020; Harbourt et al., 2020).

\section{HIERARCHY OF SUSCEPTIBILITY OF PATHOGENS INCLUDING SARS-COV-2 TO MICROBICIDES}

Infectious virus surviving in aerosols/droplets or on HITES represents a source for dissemination of emerging /re-emerging viruses, including SARS-CoV-2. The enveloped viruses listed in Tables 1 and 2 should be relatively susceptible to the virucidal activity of a variety of microbicides, as discussed below. Sattar (2007) previously has advanced the concept of utilizing the known knowledge of the susceptibility of human viral pathogens to chemical disinfecting agents (microbicides) (Klein and Deforest, 1983; McDonnell and Russell, 1999; Ijaz and Rubino, 2008), to predict the efficacy of such agents for inactivating emerging /re-emerging viral pathogens. This concept, referred to as a hierarchy of susceptibility to microbicides, is portrayed in Fig. 2. As shown, infectious agents can be viewed as displaying a continuum of susceptibilities to microbicides, with enveloped viruses at the bottom of this hierarchy, highlighting their relatively high susceptibilities to formulated microbicides (Klein and Deforest, 1983; McDonnell and Russell, 1999; Sattar 2007; Ijaz and Rubino, 2008).

Among pathogens, prions are considered to be the least sensitive to microbicides, requiring highly caustic solutions for inactivation. Bacterial spores and protozoan cysts/oocysts are next on the microbicidal susceptibility spectrum. Small, non-enveloped viruses are considered to be less susceptible to microbicides, although these viruses display increased susceptibility to high $\mathrm{pH}$, oxidizers such as sodium hypochlorite, activated hydrogen peroxide, alcohols, and a variety of microbicidal actives, relative to spores and protozoan cysts/oocysts. Mycobacteria, fungi, vegetative bacteria and enveloped viruses appear to be more susceptible to certain formulated microbicides, such as alcohols, oxidizers, quaternary ammonium compounds (QAC), and phenolics (e.g., p-chloro-m-xylenol) (Klein and Deforest, 1983; Sattar et al., 1989; McDonnell and Russell, 1999; Rabenau et al., 2005; Sattar 2007; Ijaz and Rubino, 2008; Geller et al., 2012; Cook et al., 2015; Cook et al., 2016; Cutts et al., 2018, 2019, 2020; Rutala et al., 2019; Weber et al., 2019; Chin et al., 2020; Kampf et al., 2020; O'Donnell et al., 2020;O'Donnell et al., 2020; Senghore et al., 2020; Vaughan et al., 2020; Yu et al., 2020). A number of commercially available formulated microbicides (antiseptic liquid, hand sanitizers, liquid hand wash, bar soap, surface cleanser, disinfectant wipe, and disinfectant spray) have been evaluated for virucidal efficacy against SARS-CoV-2 (Ijaz et al., 2020), and as expected, were found to cause complete inactivation ( 3.0 to $4.7 \log _{10}$ ) within the $1-5$ minute contact times tested.

It is of interest that the enveloped viruses are considered to be the most susceptible to a variety of formulated microbicidal actives, even more so than fungi and vegetative bacteria, yeast, and mycobacteria (Fig. 2). Viral envelopes are typically derived from the host cell and are, therefore, comprised of host cell phospholipids and proteins (Fig. 3), as well as some virally inserted glycoproteins. Coronaviruses are known to obtain their lipid envelopes from the host cell endoplasmic reticulum Golgi intermediate compartment, after which the particles are transported by exocytosis via cargo vesicles (reviewed in O'Donnell et al., 2020). The composition of the coronavirus lipid envelope, therefore, is determined by the lipid composition of the host cell endoplasmic reticulum. Since the envelopes contain lipid material, they are 
285

286

287

288

289

290

291

292

293

294

295

296

297

298

299

300

301

302

303

304

305

306

307

308

309

310

311

312

313

314

315

316

317

318

319

320

321

322

323

324

325

326

327

328

329

readily destroyed by phenolics such as $p$-chloro- $m$-xylenol (PCMX), oxidizing agents such as sodium hypochlorite and activated hydrogen peroxide, quaternary ammonium compounds, alcohols, and detergents. Even mild detergents, such as soap, may inactivate enveloped viruses by denaturing the lipoproteins in the envelope. These include the SARS-CoV-2 spike proteins that interact with the human angiotensin-converting enzyme 2 (ACE2) receptor as a requisite event in initiating viral infection (Letko et al., 2020). This makes enveloped viruses more susceptible to most of the formulated virucidal microbicides commonly used for IPAC.

It can be assumed as a starting point, therefore, that the enveloped emerging/re-emerging viruses listed in Table 1 should be readily inactivated by a variety of formulated microbicidal actives. This assumption has, in fact, been verified by extensive empirical data (Klein and Deforest, 1983; Sattar et al., 1989; McDonnell and Russell, 1999; Rabenau et al., 2005; Sattar 2007; Ijaz and Rubino, 2008; Geller et al., 2012; Cook et al., 2015; Cook et al., 2016; Cutts et al., 2018, 2019, 2020; Weber et al., 2019; Chin et al., 2020; Ijaz et al., 2020; Kampf et al., 2020; O'Donnell et al., 2020; O'Donnell et al., 2020; Vaughan et al., 2020; Yu et al., 2020; Castaño et al., 2020), and has been embraced by the U.S. Environmental Protection Agency (U.S. EPA, 2016). The data for various members of the Coronaviridae family, reviewed recently by Kampf et al. (2020), Cimolai (2020), and Golin et al. (2020) support the expectation that SARS-CoV-2 and other coronaviruses of concern (e.g., MERS-CoV, SARS-CoV, mouse hepatitis virus, porcine epidemic diarrhea virus, etc.) should be readily inactivated by commonly employed and commercially available formulated microbicides, including QAC. Virucidal efficacy testing results for SARS-CoV-2 reported by Ijaz et al. (2020) also confirm the expectation of susceptibility of this coronavirus to a variety of microbicidal actives. In addition, a recently issued European guidance document (European Centre for Disease Prevention and Control, 2020) lists a variety of microbicidal agents that have demonstrated efficacy against a variety of human and animal coronaviruses and that, therefore, could be applied for decontamination of surfaces in non-healthcare facilities.

Aqueous solutions of the phenolic PCMX at concentrations of $0.12-0.48 \%$ by weight were shown to inactivate $>4 \log _{10}$ of infectious Ebola virus - Makona variant (EBOV/Mak) suspended in an organic load and evaluated in liquid virucidal efficacy studies (Cutts et al., 2018; 2019) or dried on a steel surface (a prototypic HITES) in a hard surface carrier viricidal efficacy study (Cutts et al., 2018). In each case, complete inactivation of $\geq 6.8 \log _{10}$ of EBOV/Mak was observed after contact times $\geq 5 \mathrm{~min}$. In addition, EBOV/Mak dried on prototypic steel carriers was completely inactivated $\left(\geq 6.5 \log _{10}\right.$ ) by aqueous solutions of $70 \%$ ethanol or $0.5 \%$ or $1 \%$ $\mathrm{NaOCl}(\geq 0.5 \%)$ after contact times $\geq 2.5 \mathrm{~min}$ (Cook et al., 2015). Disinfectant pre-soaked wipes containing, as active ingredients, either activated hydrogen peroxide or a QAC were found to have virucidal efficacy $\left(>5 \log _{10}\right)$ for EBOV/Mak and vesicular stomatitis virus following as little as 5 seconds contact time (Cutts et al., 2020).

Microbicidal formulations based on oxidizing agents, QAC, alcohols, phenolics, and aldehydes displaying virucidal efficacy for enveloped viruses and relatively less susceptible nonenveloped viruses (such as human norovirus surrogates) have been recommended for decontaminating environmental surfaces or materials used for food preparation (Zonta et al., 2016; Scott et al., 2020). The efficacy of ethanol and QAC actives for inactivating the norovirus surrogate feline calicivirus depends on how the microbicides are formulated. Factors, such as the addition of an alkaline agent, were found to increase their efficacy (Whitehead and McCue, 2010). Microbicides satisfying these requirements can be regarded as effective against 
330

emerging/re-emerging viruses, such as SARS-CoV-2. Following this logic, the U.S. EPA has invoked an Emerging Viral Pathogen Policy in the past for pandemic influenza, for the Ebola virus, and most recently, for SARS-CoV-2 (U.S. EPA, 2020).

In the case of highly pathogenic emerging/re-emerging viruses, such as SARS-CoV-2, effective and frequent targeted hygiene using appropriate microbicides is essential for prevention of infectious virus dissemination. Practicing hygiene inappropriately and only once daily may not be sufficient, as recontamination of HITES could potentially occur, particularly under healthcare settings where SARS-CoV-2 infected patients are treated. For instance, infectious coronavirus 229E was detected on HITES (e.g., door knobs) in a university classroom in which samples were collected daily over a one-week period (Bonny et al., 2018). Vigilant decontamination of HITES becomes of paramount importance in high risk areas, such as intensive care units (Zhang, 2020). This is especially true when dealing with highly pathogenic viruses with relatively low human infectious doses, as is the case with many of the emerging/reemerging viruses, and likely including SARS-CoV-2, being discussed in this review.

The enveloped emerging/re-emerging viruses listed in Table 1 display high susceptibility to inactivation by ultraviolet light at $254 \mathrm{~nm}$, an inactivation approach amenable to inactivation of aerosolized viruses (Ijaz et al., 1985). For instance, empirical data (Lytle and Sagripanti, 2005) for Lassa virus, Hantavirus, and Ebola virus, and for the virus families Coronaviridae, Orthomxyoviridae, Paramyxoviridae, Phenuiviridae, indicate that UV fluencies of 3 to 14 $\mathrm{mJ} / \mathrm{cm}^{2}$ should inactivate $4 \log _{10}$ of the enveloped viruses in Table 1 . The susceptibility of coronaviruses, including $\mathrm{HCoV}-229 \mathrm{E}$, SARS-CoV, and MERS- CoV, to UV irradiation has been reviewed recently (Heßling et al., 2020). Characterization of the UV-C susceptibility of SARSCoV-2 has also been evaluated (Bianco et al., 2020). In that study, a fluency of $3.7 \mathrm{~mJ} / \mathrm{cm}^{2}$ resulted in $3 \log _{10}$ inactivation. These fluency values are relatively low, compared to those needed to inactivate $4 \log _{10}$ of the least UV-susceptible viruses, such as those of the Adenoviridae $\left(98-222 \mathrm{~mJ} / \mathrm{cm}^{2}\right)$ and Polyomaviridae $\left(235-364 \mathrm{~mJ} / \mathrm{cm}^{2}\right)$ families of non-enveloped viruses (Nims and Plavsic, 2014).

\section{PERSONAL HYGIENE PRACTICES FOR PREVENTING INFECTIOUS VIRUS ACQUISITION}

The WHO has posted a webpage entitled "Coronavirus Disease (COVID-19) advice for the public" (WHO, 2020b). Basic protective measures against SARS-CoV-2 recommended by the WHO include: frequent hand washing with soap and water or an alcohol-based rub and maintenance of social distancing (at least $1 \mathrm{~m}$; see Fig. 1), especially in the presence of people who are coughing, sneezing, or have a fever ( $W H O, 2020 b)$. The latter recommendation is applicable to any of the viruses listed in Table 2, for which transmission by respiratory aerosols/droplets is expected. Avoidance of touching eyes, nose, mouth, or other mucous membranes with hands after contact with HITES is also recommended ( $W H O, 2020 b)$. As displayed in Fig. 1, the hands play an important role in transfer of infectious virus from contaminated HITES to a susceptible mucous membrane, enabling virus-host interactions initiating infection. Following the appropriate hygiene practices described above can potentially help in prevention and control of emerging and re-emerging viruses, including the currently circulating SARS-CoV-2.

The U.S. CDC has posted a webpage entitled "Coronavirus 2019 (COVID-19) How to protect yourself and others" (U.S. CDC, 2020). This includes a brief description of the primary modes of 
374

375

376

transmission of the virus, advice on handwashing (especially situations after which hand washing should be done), advice on social distancing, admonitions on use of face coverings, targeted hygiene of frequently touched surfaces (HITES), and self-monitoring of health.

While handwashing practices practically can be applied in developed countries, there are still some three billion people in developing countries without access to basic handwashing facilities in the home and where proper hand hygiene may not be practiced in the majority of healthcare facilities (Mushi and Shao, 2020). Basic infection prevention and control practices, such as those mentioned by the WHO and by the U.S. CDC, are applicable not only to the current SARS-CoV2 pandemic, but also to any emerging outbreaks involving enveloped viruses, which are highly susceptible to hand washing using soap and water and alcohol-based hand rubs and to surface hygiene using commonly employed household disinfectants.

\section{DISCUSSION}

As Dr. Anthony Fauci eloquently stated in 2005 (Fauci, 2005), "Public health officials once suggested that it might someday be possible to 'close the book' on the study and treatment of infectious diseases. However, it is now clear that endemic diseases as well as newly emerging ones (e.g., SARS-CoV-2), reemerging ones (e.g., West Nile virus), and even deliberately disseminated infectious diseases (e.g., anthrax from bioterrorism) continue to pose a substantial threat throughout the world." Recent experience certainly verifies these predictions. Weber et al. (2019) have correctly emphasized that "Preventing pathogen acquisition via person-to-person transmission or contact with the contaminated environment depends on rapid and appropriate institution of isolation precautions, appropriate hand hygiene, and appropriate disinfection of medical equipment, devices, and the environmental. Importantly, once the nature of the emerging infectious agent is known (i.e., enveloped virus, bacteria, fungi, nonenveloped virus, mycobacteria, or non-enveloped virus), it is possible to determine the appropriate hygienic interventions. For example, an enveloped virus (e.g., Ebola, MERS-CoV, SARS-CoV-2, or any of the cornaviruses) or vegetative bacterium (e.g., CRE, MRSA) would be inactivated by any formulated microbicidal active(s) known to be effective against vegetative bacteria, filamentous fungi, -mycobacteria, or non-enveloped viruses." (Weber et al., 2019).

It is fortunate that so many of the emerging/re-emerging viruses (examples listed in Table 1 and below) are enveloped viruses. It is not clear why there are not more small, non-enveloped viruses mentioned in the WHO list of viral diseases of concern (WHO, 2015). The small nonenveloped viruses are much less susceptible to commonly employed cleaning agents (antiseptics, detergents, microbicidal actives) and, in general, display relatively longer survival on environmental surfaces. According to theoretical modeling of sustained person-to-person transmissibility (Geoghegan et al., 2016; Walker et al., 2018; Munster et al., 2020), small nonenveloped viruses are predicted to be more likely to lead to sustained infections within the community. The reality is that the emerging/re-emerging viruses of concern, both in humans and in economically important animals, have more typically included enveloped viruses. Recent examples include porcine epidemic diarrhea virus, MERS-CoV, SARS-CoV and SARS-CoV-2 (Coronaviridae), African swine fever virus (Asfarviridae), Schmallenberg virus (Peribunyaviridae), Crimean-Congo hemorrhagic fever virus (Nairoviridae), Rift Valley fever virus (Phenuiviridae), West Nile virus and Zika virus (Flaviviridae), Hantaviruses (Hantaviridae), and Lassa viruses (Bunyaviridae). 
417

The fact that the emerging/re-emerging viruses are predominantly RNA viruses might be explained in part by the notion (Jaijyan et al., 2018) that RNA viruses can more readily adapt to the rapidly changing global and local environment due to the high error rate of the polymerases that replicate their genomes. The RNA viruses are thought, therefore, to display higher evolution rates through mutation, genomic reassortment, or recombination.

In our review of articles pertaining to SARS-CoV-2 IPAC, we have identified several knowledge gaps. These include the fact that contamination of surfaces in the vicinity of COVID19 patients (i.e., contamination hot-spots) has primarily been described on the basis of measurement of SARS-CoV-2 RNA, and not on the basis of recovery of infectious virus using cell-based assays. The measurement of RNA does not inform as to the infection potential of the surface contamination. Similarly, articles describing the contamination of waste-water streams by SARS-CoV-2 have been based on measurement of viral RNA, not infectious virus. As a result, it is not presently known whether infectious virus is present in such waste streams and, therefore, whether the finding of viral RNA in waste water represents real risk in terms of onward dissemination of the virus. Another knowledge gap, that has already been mentioned above, is the true mortality rates for the various emerging/re-emerging viruses addressed in this review. As these viral infections are relatively deadly, empirical data on true mortality rates are lacking. For the same reason, accurate data on human MID are not generally available for these viruses. The risk of acquiring an infection of one of these viruses from a contaminated environmental surface, over a period of time following an initial contamination event, will remain difficult to assess until such knowledge gaps have been resolved.

\section{CONCLUSIONS}

The likelihood of experiencing future emergent zoonotic viruses is high (Morens and Fauci, 2013; Paules et al., 2020), and defining in advance appropriate approaches for limiting the spread of such viruses through IPAC is essential. We now have the sequencing tools necessary for rapidly identifying a novel virus such as SARS-CoV-2, the genetic sequence of which was determined within just over one week (Zhu et al., 2020). Provided that a novel emerging virus is found to be a member of a lipid-enveloped viral family, it should be possible to leverage IPAC experience for other enveloped viruses of concern, and thereby make predictions as to risk of viral transmission, virus survival on surfaces, and microbicidal efficacy for the virus and risk mitigation. SARS-CoV-2 is no exception in this regard.

\section{REFERENCES}

Aboubakr HA, Sharafeldin TA, Goyal SM. 2020. Stability of SARS-CoV-2 and other coronaviruses in the environment and on common touch surfaces and the influence of climatic conditions: a review. Transboundary and Emerging Diseases https://doi.org/10.1111/tbed.13707

Ang BSP, Lim TCC, Wang L. 2018. Nipah virus infection. Journal of Clinical Microbiology 56:e01875-17. doi.org/10.1128/JCM.01875-17.

Anonymous. 2013. Middle East Respiratory Syndrome Coronavirus. https://www.aabb.org/tm/eid/Documents/middle-east-respiratory-syndrome-coronavirus.pdf 
458

Bailey ES, Fieldhouse JK, Choi JY, Gray GC. 2018. A mini review of the zoonotic threat potential of influenza viruses, coronaviruses, adenoviruses, and enteroviruses. Frontiers in Public Health 6:104. doi: 10.3389/fpubh.2018.00104 (2018).

Bianco A, Biasin M, Pareschi G, Cavaliere A, Cavatorta C, Fenizia C, Galli P, Lessio L, Lualdi M, Redaelli E, Saulle I, Trabattoni D, Zanutta A, Clerici M. 2020. UV-C irradiation is highly effective in inactivating and inhibiting SARS-CoV-2 replication. medRxiv 2020.06.05.20123463; doi: https://doi.org/10.1101/2020.06.05.20123463

Bibby K, Fischer RJ, Casson LW, de Carvalho NA, Haas CN, Munster VJ. 2017. Disinfection of Ebola virus in sterilized municipal wastewater. PLoS Neglected Tropical Diseases 11:e0005299.doi:10.1371/journal/pntd.005299.

Bonny TS, Yezli S, Lednicky JA. 2018. Isolation and identification of human coronavirus $229 \mathrm{E}$ from frequently touched environmental surfaces of a university classroom that is cleaned daily. American Journal of Infection Control 46(1):105-107.

Brocato RL, Hooper JW. 2019. Progress on the prevention and treatment of hantavirus disease. Viruses 11:610: doi:10.3390/v11070610 (2019).

Cassidy H, Poelman R, Knoester M, Van Leer-Buter CC, Niesters HGM. 2018. Enterovirus D68 - the new polio? Frontiers in Microbiology 9:2677: doi:10.3389/fmicb.2018.02677.

Castaño N, Cordts S, Jalil MK, Zhang K, Koppaka S, Bick A, Paul R, Tang SKY. 2020. Fomite transmission and disinfection strategies for SARS-CoV-2 and related viruses. arXiv:2005.11443 [q-bio.OT\}. https://arxiv.org/abs/2005.11443

Chan KH, Malik Peiris JS, Lam SY, Poon LLM, Yuen KY, Seto WH. 2011. The effects of temperature and relative humidity on the viability of the SARS coronavirus. Advances in Virology 734690, doi:10.1155/2011/734690.

Chin AWH, Chu JTS, Perera MRA, Hui KPY, Yen H-L, Chan MCW, Peiris M, Poon JJM. 2020. Stability of SARS-CoV-2 in different environmental conditions. The Lancet Microbe 1(1): https://doi.org/10.1016/ S2666-5247(20)30003-3

Cieslak TJ, Herstein JJ, Kortepeter MG, Hewlett AL. 2019. A methodology for determining which diseases warrant care in a high-level containment care unit. Viruses 11(9): 773; doi:10.3390/v11090773.

Cimolai N. 2020. Environmental and decontamination issues for human coronaviruses and their potential surrogates. Journal of Medical Virology 1-13. Doi: 10.1002/jmv.26170

Cook BWM, Cutts TA, Nikiforuk AM, Leung A, Kobasa D, Theriault SS. 2016. The disinfection characteristics of Ebola virus outbreak variants. Scientific Reports 6:38293 https://doi.org/10.1038/srep38293.

Cook BWM, Cutts TA, Nikiforuk AM, Poliquin PG, Court DA, Strong JE, Theriault SS. 2015. Evaluating environmental persistence and disinfection of Ebola virus Makona variant. Viruses 7(4):1975-1986. 
496
Cutts TA, Ijaz MK, Nims RW, Rubino JR, Theriault SS. 2018. Efficacy of Dettol Antiseptic Liquid for inactivation of Ebola-Makona virus suspended in an organic load - a targeted hygiene intervention for reducing virus spread. International Conference on Emerging Infectious Diseases (ICEID 2018) Atlanta Georgia, USA; Board LB-78. https://www.cdc.gov/iceid/docs/ICEID-2018-program-book-P.pdf

Cutts TA, Ijaz MK, Nims RW, Rubino JR, Theriault SS. 2019. Effectiveness of Dettol Antiseptic Liquid for inactivation of Ebola virus in suspension. Scientific Reports. 9:6590 doi.org/10.1038/s41598-019-42386-5.

Cutts TA, Robertson C, Theriault SS, Nims RW, Kasloff SB, Rubino JR, Ijaz MK. 2020. Assessing the contributions of inactivation, removal, and transfer of Ebola virus and vesicular stomatitis virus by disinfectant pre-soaked wipes. Frontiers in Public Health 8:183, doi:10.3389/fpubh.2020.00183

European Centre for Disease Prevention and Control. 2020. Interim guidance for environmental cleaning in non-healthcare facilities exposed to SARS-CoV-2. https://www.ecdc.europa.eu/en/publications-data/interim-guidance-environmental-cleaningnon-healthcare-facilities-exposed-2019

Fauci AS. 2005. Emerging and reemerging infectious diseases: The perpetual challenge. Academic Medicine 80(12):1079-1085.

Fieldhouse JK, Wang X, Mallinson KA, Tsao RW, Gray GC. 2018. A systematic review of evidence that enteroviruses may be zoonotic. Emerging Microbes \& Infections 7:164. doi.org/10.1038/s41426-018-0159-1 (2018).

Fischer R, Judson S, Miazgowicz K, Bushmaker T, Prescott J, Munster VJ. 2015. Ebola virus stability on surfaces and in fluids in simulated outbreak environments. Emerging Infectious Diseases 21(7):1243-1246.

Francis R, Le Bideau M, Jardot P, Grimaldier C, Raoult D, Bou Kalil JY, la Scola B. 2020. High speed large scale automated isolation of SARS-CoV-2 from clinical samples using miniaturized co-culture with high content screening. bio $R_{x} i v$ doi: https://doi.org/10.1101/2020.05.14.097295

Franz DR, Jahrling PB, Friedlander AM, McClain DJ, Hoover DL, Bryne WR, Pavlin JA, Christopher GW, Eitzen EM Jr. 1997. Clinical recognition and management of patients exposed to biological warfare agents. Journal of the American Medical Association 278(5):399-411.

Furukawa NW, Brooks JT, Sobel J. 2020. Evidence supporting transmission of severe acute respiratory syndrome coronavirus 2 while presymptomatic or asymptomatic. Emerging Infectious Diseases 26(7): https://doi.org/10.3201/eid2607.201595

Gandhi M, Yokoe DS, Havlir DV. 2020. Asymptomatic transmission, the Achilles' heel of current strategies to control COVID-19. The New England Journal of Medicine DOI: 10.1056/NEJMe2009758 
534

Geoghegan JL, Senior AM, Di Giallonardo F, Holmes EC. 2016. Virological factors that increase transmissibility of emerging human viruses. Proceedings of the National Academy of Sciences of the United States of America 113(15):4170-4175.

Geller C, Varbanov M, Duval RE. 2012. Human coronaviruses: insights into environmental resistance and its influence on the development of new antiseptic strategies. Viruses 4(11):3044-3068.

Golin AP, Choi D, Ghahary A. 2020. Hand sanitizers: a review of ingredients, mechanisms of action, modes of delivery, and efficacy against coronaviruses. American Journal of Infection Control in press: https://doi.org/10.1016/j.ajic.2020.06.182

Gorbalenya AE, Baker SC, Baric RS, de Groot RJ, Drosten C, Gulyaeva AA, Haagmans BJ, Lauber C, Leontovich AM, Neuman BW, Penzar D, Perlman S, Poon LLM, Samborskiy DV, Sidorov IA, Sola I, Ziebuhr J. 2020. The species Severe acute respiratory syndrome-related coronavirus: classifying 2019-nCoV and naming it SARSCoV-2. Nature Microbiology 5:536-544.

Guo Z-D, Wang Z-Y, Zhang S-F, Li X, Li L, Li C, Cui Y, Fu R-B, Dong Y-Z, Chi X-Y, Zhang M-Y, Liu K, Cao C, Liu B, Zhang K, Gao Y-W, Lu B, Chen W. 2020. Aerosol and surface distribution of severe acute respiratory syndrome coronavirus 2 in hospital wards, Wuhan, China, 2020. Emerging Infectious Diseases 26:

https://wwwnc.cdc.gov/eid/article/26/7/20-0885_article

Haas CN, Rose JB, Gerba CP. 2014. Quantitative Microbial Risk Assessment. John Wiley, NY.

Harbourt DE, Haddow AD, Piper AE, Bloomfield H, Kearney BJ, Fetterer D, Gibson K, Minogue T. 2020. Modeling the stability of severe acute respiratory syndrome coronavirus 2 (SARS-CoV-2) on skin, currency, and clothing. $m e d R_{x} i v$ doi: https://doi.org/10.1101/2020.07.01.20144253 Accessed July 2020.

Hardestam J, Simon M, Hedlund KO, Vaheri A, Klingström J, Lundkvist, Å. 2007. Ex vivo stability of the rodent-borne Hantaan virus in comparison to that of arthropod-borne members of the Bunyaviridae family. Applied Environmental Microbiology 73(8):25472551.

Hassan MZ, Sazzad HMS, Luby SP, Sturm-Ramirez K, Bhuiyan MU, Rahman MZ, Islam MM, Ströher U, Sultana S, Kafi MAH, Daszak P, Rahman M, Gurley ES. 2018. Nipah virus contamination of hospital surfaces during outbreaks, Bangladesh, 2013-2014. Emerging Infectious Diseases 24(1):15-21.

Heßling M, Hönes K, Vatter P, Lingenfelder C. 2020. Ultraviolet irradiation doses for coronavirus inactivation - review and analysis of coronavirus photoinactivation studies. GMS Hygiene and Infection Control 15: doi: 10.3205/dgkh000343

Ijaz MK, Brunner AH, Sattar SA, Nair RC, Johnson-Lussenburg CM. 1985. Survival characteristics of airborne human coronavirus. Journal of General Virology 66:2743-2748. 
572

573

574

575

576

577

578

579

580

581

582

583

584

585

586

587

588

589

590

591

592

593

594

595

596

597

598

599

600

601

602

603

604

605

606

607

608

Ijaz MK, Rubino JR. 2008. Should test methods for disinfectants use vertebrate virus dried on carriers to advance virucidal claims? Infection Control Hospital Epidemiology 29(2):192194.

Ijaz MK, Whitehead K, Srinivasan V, McKinney J, Rubino JR, Ripley M, Jones C, Nims RW, Charlesworth B. 2020. Microbicidal actives with virucidal efficacy against SARS-CoV-2. American Journal of Infection Control 48(8):972-973.

Ijaz MK, Zargar B, Wright K, Rubino JR, Sattar SA. 2016. Generic aspects of the airborne spread of human pathogens indoors and emerging air decontamination technologies. American Journal of Infection Control 44(9):A109-S120.

Jaijyan DK, Liu J, Hai R, Zhu H. 2018. Emerging and reemerging human viral diseases. Annals of Microbiology Research 2(1):31-44.

Jiang F-C, Jiang X-L, Wang Z-G, Meng Z-H, Shao S-F, Anderson BD, Ma N-J. 2020. Detection of severe acute respiratory syndrome coronavirus 2 RNA on surfaces in quarantine rooms. Emerging Infectious Diseases 26(9):https://doi.org/10.3201/eid2609.201435

Jiang H, Du H, Wang LM, Wang PZ, Bai XF. 2016. Hemorrhagic fever with renal syndrome: pathogenesis and clinical picture. Frontiers in Cellular and Infection Microbiology 6:1: doi: 10.3389/fcimb.2016.00001 (2016).

Kampf G, Todt D, Pfaender S, Steinmann E. 2020. Persistence of coronaviruses on inanimate surfaces and its inactivation with biocidal agents. The Journal of Hospital Infection 104(3):246-251, and corrigendum: The Journal of Hospital Infection 105:587.

Kasloff SB, Strong JE, Funk D, Cutts TA. 2020. Stability of SARS-CoV-2 on critical personal protective equipment. medRxiv https://doi.org/10.1101/2020.06.11.20128884 Accessed July 2020.

Killerby ME, Biggs HM, Midgley CM, Gerber SI, Watson JT. 2020. Middle East respiratory syndrome coronavirus transmission. Emerging Infectious Diseases 26(2):191198.

Klein M, Deforest A. 1983. Principles of viral inactivation. In: Block SS, editor. Disinfection, sterilization, and preservation, 3rd edition: Philadelphia: Lea and Febiger; $\mathrm{p}$. 422-434.

Krüger DH, Schönrich G, Klempa B. 2011. Human pathogenic hantaviruses and prevention of infection. Human Vaccines 7(6):685-693.

Laenen L, Vergote V, Calisher CH, Klempa B, Klingström J, Kuhn JH, Maes P. 2019. Hantaviridae: current classification and future perspectives. Viruses 11(9) :doi: 10.3390/v11090788.

Letko M, Marzi A, Munster V. 2020. Functional assessment of cell entry and receptor usage for SARS-CoV-2 and other lineage B betacoronaviruses. Nature Microbiology 5:562569. 
609

610

611

612

613

614

615

616

617

618

619

620

621

622

623

624

625

626

627

628

629

630

631

632

633

634

635

636

637

638

639

640

641

642

643

644

645

646

647

648

Li W, Shi Z, Yu M, Ren W, Smith C, Epstein JH, Wang H, Crameri G, Hu Z, Zhang H, Zhang J, McEachern J, Field H, Daszak P, Eaton BT, Zhang S, Wang L-F. 2020. Bats are natural reservoirs of SARS-like coronaviruses. Science 310:676-679.

Lytle CD, Sagripanti J-L. 2005. Predicted inactivation of viruses of relevance to biodefense by solar radiation. Journal of Virology 79(22):14244-14252.

Maillard J-Y, Sattar SA, Pinto F. 2013. Virucidal activity of microbicides. In Russell, Hugo \& Ayliffe's: Principles and Practice of Disinfection, Preservation and Sterilization, 5th Edition, Fraise AP, Maillard J-Y, Sattar A (eds). https://doi.org/10.1002/9781118425831.ch9

McDonnell G, Russell AD. 1999. Antiseptics and disinfectants: activity, action, and resistance. Clinical Microbiology Reviews 12(1):147-179.

Morawska L, Tang JW, Bahnfleth W, Bluyssen PM, Boerstra A, Buonanno G, Cao J, Dancer S, Floto A, Franchimon F, Haworth C, Hoegling J, Isaxon C, Jimenez JL, Kurnitski J, Li Y, Loomans M, Marks G, Marr LC, Mazzarella L, Melikov AK, Miller S, Milton DK, Nazaroff W, Nielsen PV, Noakes C, Peccia J, Querol X, Sekhar C, Seppänen O, Tanabe S, Tellier R, Tham KW, Wargocki P, Wierzbicka A, Yao M. 2020. How can airborne transmission of COVID-19 indoors be minimized? Environment International 142:105832. doi:10.1016/j.envint.2020.105832

Morens DM, Fauci AS. 2013. Emerging infectious diseases: threats to human health and global stability. PLoS Pathogens 9:e1003467. https://doi.org/10.1371/journal.ppat.1003467

Munster VJ, Koopmans M, van Doremalen N, van Riel D, de Witt E. 2020. A novel coronavirus emerging in China - key questions for impact assessment. The New England Journal of Medicine 382(8):692-694.

Mushi V, Shao M. 2020. Tailoring of the ongoing water, sanitization and hygiene interventions for prevention and control of COVID-19. Tropical Medicine and Health 48:47 doi: 10.1186/s41182-020-00236-5

Nims R, Plavsic M. 2014. Identification of worst-case model viruses for selected viral clearance steps. Bioprocessing Journal 13(2):6-13.

Nolte KB, Feddersen RM, Foucar K, Zaki SR, Koster FT, Madar D, Merlin TL, McFeeley PJ, Umland ET, Zumwalt RE. 1995. Hantavirus Pulmonary Syndrome in the United States: a pathological description of a disease caused by a new agent. Human Pathology 26(1):110-120.

O'Donnell VB, Thomas D, Stanton R, Maillard J-Y, Murphy RC, Jones SA, Humphreys I, Wakelam MJO, Fegan C, Wise MP, Bosch A, Sattar SA. 2020. Potential role of oral rinses targeting the viral lipid envelope in SARS-CoV-2 infection. Function zqaa002, https://doi.org/10.1093/function/zqaa002

Oermann CM, Schuster JE, Conners GP, Newland JG, Selvarangan R, Jackson MA. 2015. Enterovirus D68: A focused review and clinical highlights from the 2014 U.S. outbreak. Annals of the American Thoracic Society 12(5):775-781.

Ong SWX, Tan YK, Chia PY, Lee TH, Ng OT, Wong MSY, Marimuthu K. 2020. Air, surface environmental, and personal protective equipment contamination by severe acute 
649

respiratory syndrome coronavirus 2 (SARS-CoV-2) from a symptomatic patient. Journal of the American Medical Association 323(16):1610-1611.

Otter JA, Donskey C, Yezli S, Douthwaite S, Goldenberg SD, Weber DJ. 2011. Transmission of SARS and MERS coronaviruses and influenza virus in healthcare settings: the possible role of dry surface contamination. The Journal of Hospital Infection 92(3):235250 .

Pastorino B, Touret F, Gilles M, de Lamballerie X, Charr RN. 2020. Prolonged infectivity of SARS-CoV-2 in fomites. Emerging Infectious Diseases 26(9): https://doi.org/10.3201/eid2609.201788

Patel KP, Vunnam SR, Patel PA, Krill KL, Korbitz PM, Gallagher JP, Suh JE, Vunnam RR. 2020. Transmission of SARS-CoV-2: An update of current literature. European Journal of Clinical Microbiology and Infectious Disease https://doi.org/10.1007/s10096-020-03961-1

Paterson BJ, Mackenzie JS, Durrheim DN, Smith D. 2011. A review of the epidemiology and surveillance of viral zoonotic encephalitis and the impact on human health in Australia. New South Wales Public Health Bulletin. 22(5-6):99-104.

Paules CI, Marston HD, Fauci AS. 2020. Coronavirus infections - more than just the common cold. Journal of the American Medical Association 323(8):707-708.

Piercy TJ, Smither SJ, Steward JA, Eastaugh L, Lever MS. 2010. The survival of filoviruses in liquids, on solid substrates and in a dynamic aerosol. Journal of Applied Microbiology 109(5):1531-1539.

Rabenau HF, Cinatl J, Morgenstern B, Bauer G, Preiser W, Doerr HW. 2005. Stability and inactivation of SARS coronavirus. Medical Microbiology and Immunology 194:1-6.

Rutala WA, Kanamori H, Gergen MF, Sickbert-Bennett EE, Weber DJ. 2019.

Susceptibility of Candida auris and Candida albicans to 21 germicides used in healthcare facilities. Infection Control Hospital Epidemiology 40(3):380-382.

Sagripanti J-L, Rom AM, Holland LE. 2010. Persistence in darkness of virulent alphaviruses, Ebola virus, and Lassa virus deposited on solid surfaces. Archives of Virology 155:2035-2039.

Santarpia JL, Herrera VL, Rivera DN, Ratnesar-Shumate S, Reid SP, Denton PW, Martens JWS, Fang Y, Conoan N, Callahan MV, Lawler JV, Brett-Major DM, Lowe JJ. 2020. The infectious nature of patient-generated SARS-CoV-2 aerosol. medRxiv doi: https://doi.org/10.1101/2020.07.13.20041632

Santarpia JL, Rivera DN, Herrera V, Morwitzer NJ, Creager H, Santarpia GW, Crown KK, Brett-Major DM, Schnaubelt E, Broadhurst MJ, Lawler JV, Reid SP, Lowe JJ. 2020. Aerosol and surface transmission potential of SARS-CoV-2. medRxiv 2020.03.23.20039446; doi: https://doi.org/10.1101/2020.03.23.20039446

Sattar SA. 2007. Hierarchy of susceptibility of viruses to environmental surface disinfectants: a predictor of activity against new and emerging viral pathogens. Journal of AOAC International 90(6): 1655-1658. 
689
Sattar SA, Karim YG, Springthorpe VS, Johnson-Lussenburg CM. 1987. Survival of human rhinovirus type 14 dried onto nonporous inanimate surfaces: effect of relative humidity and suspending medium. Canadian Journal of Microbiology 33(9):802-806.

Sattar SA, Springthorpe VS, Karim Y, Loro P. 1989. Chemical disinfection of non-porous inanimate surfaces experimentally contaminated with four human pathogenic viruses. Epidemiology and Infection 102(3):493-505.

Scott E, Bruning E, Ijaz MK. 2020. Decontamination of environmental surfaces in everyday settings. In: McDonnell G, Hansen J, editors. Block's disinfection, sterilization, and preservation, 6th edition: Philadelphia: Wolters Kluwer; in press.

\section{Senghore M, Diarra B, Gehre F, Otu J, Worwui A, Muhammad AK, Kwambana-} Adams B, Kay GL, Sanogo M, Baya B, Orsega S, Doumbia S, Diallo S, de Jong BC, Pallen MJ, Antonio M. 2020. Evolution of Mycobacterium tuberculosis complex lineages and their role in an emerging threat of multidrug resistant tuberculosis in Bamako, Mali. Scientific Reports 10:327 doi: 10.1038/s41598-019-56001-0.

Sia S-F, Yan L-M, Chin AWH, Fung K, Choy K-T, Wong AYL, Kaewpreedee P, Perera RAPM, Poon LLM, Nicholls JM, Peiris M, Yen H-L. 2020. Pathogenesis and transmission of SARS-CoV-2 in golden hamsters. Nature https://doi.org/10.1038/s41586-020-2342-5

Stephenson EH, Larson EW, Dominik JW. 1984. Effect of environmental factors on aerosol-induced Lassa virus infection. Journal of Medical Virology 14(4):295-303.

St. Georgiev V. 2009. Chapter 23. Defense against biological weapons (biodefense). Frontiers in Research. Springer

Sun J, Hu X-Y, Yu X-F. 2019. Current understanding of human enterovirus D68. Viruses 11(6):490; doi:10.3390/v11060490.

United States Centers for Disease Control and Prevention. 2015. Highly pathogenic Asian avian influenza A (H5N1) in people. https://www.cdc.gov/flu/avianflu/h5n1people.htm

United States Centers for Disease Control and Prevention. 2020. Coronavirus 2019 (COVID-19) How to protect yourself and others. Available at: https:/www.cdc.gov/coronavirus/2019-ncov/prevent-getting-sick/prevention.html Accessed July 2020.

United States Environmental Protection Agency. 2014. Persistence of categories A and B select agents in environmental matrices. EPA/600/R-14/074

United States Environmental Protection Agency. 2016. Guidance to Registrants: Process for Making Claims against Emerging Viral Pathogens not on EPA-Registered Disinfectant Labels. https://www.epa.gov/sites/production/files/201609/documents/emerging viral pathogen program guidance final $819 \quad 16001$ 0.pdf

United States Environmental Protection Agency. 2020. Coronavirus Cases Trigger EPA Rapid Response. https:/www.epa.gov/pesticides/coronavirus-cases-trigger-epa-rapidresponse 
van Doremalen N, Bushmaker T, Morris DH, Holbrook MG, Gamble A, Williamson BN, Tamin A, Harcourt JL, Thornburg NJ, Gerber SI, Lloyd-Smith JO, de Wit E, Munster VJ. 2020. Aerosol and surface stability of SARS-CoV-2 as compared with SARSCoV-1. The New England Journal of Medicine 382:1564-1567.

van Doremalen N, Bushmaker T, Munster VJ. 2013. Stability of Middle East respiratory syndrome coronavirus (MERS-CoV) under different environmental conditions.

733

734 Eurosurveillance 18(38):pii+20590, doi.org/10.2807/1560-7917.ES2013.18.38.20590

Vaughan A, Aarons E, Astbury J, Brooks T, Chand M, Flegg P, Hardman A, Harper N, Jarvis R, Mawdsley S, McGivern M, Morgan D, Morris G, Nixon G, O'Conner C, Palmer R, Phin N, Price DA, Russell K, Said B, Schmid ML, Vivancos R, Walsh A, Welfare W, Wilburn J, Dunning J. 2020. Human-to-human transmission of monkeypox virus, United Kingdom, October 2018. Emerging Infectious Diseases 26(4):782-785.

Viral Hemorrhagic Fever Consortium. 2020. Lassa https://vhfc.org/diseases/lassa/

Walker JW, Han BA, Ott IM, Drake JM. 2018. Transmissibility of emerging viral zoonoses. PLoS ONE 13(11):e0206926. doi.org/10.1371/journal.pone.0206926. different types of clinical specimens. Journal of the American Medical Association 323(18): $1843-1844$.

Watanabe T, Bartrand TA, Weir MH, Omura T, Haas CN. 2010. Development of a dose-response model for SARS coronavirus. Risk Analysis 30(7):1129-1138.

Weber DJ, Sickbert-Bennett EE, Kanamori H, Rutala WA. 2019. New and emerging infectious diseases (Ebola, Middle Eastern Respiratory Syndrome coronavirus, carbapenemresistant Enterobacteriacae, Candida auris): Focus on environmental survival and germicide susceptibility. American Journal of Infection Control 47:A29-A38.

753

Westwood JCN, Sattar SA. 1974. The minimal infective dose: can it establish infection? International Conference on "Viruses in Water", Mexico City, Mexico.

755

Whitehead K, McCue KA. 2010. Virucidal efficacy of disinfectant actives against feline calicivirus, a surrogate for norovirus, in a short contact time. American Journal of Infection Control 38(1):26-30.

Widders A, Broom A, Broom J. 2020. SARS-CoV-2: the viral shedding vs. infectivity dilemma. Infection, Disease \& Health S2468-0451(20)30028-6. doi:10.1016/j.idh.2020.05.002

762

Wood JP, Choi YW, Chappie DJ, Rogers JV, Kaye JZ. 2010. Environmental persistence of a highly pathogenic avian influenza (H5N1) virus. Environmental Science and Technology 44(19):7515-7520. cause major epidemics. Https://www.who.int/medicines/ebola-treatment/WHO-list-of-topemerging-diseases/en/ 
World Health Organization. 2020a. Novel Coronavirus (2019-nCoV). https://www.who.int/emergencies/diseases/novel-coronavirus-2019

World Health Organization. 2020b. Coronavirus disease (COVID-19) advice for the public. https://www.who.int/emergencies/diseases/novel-coronavirus-2019/advice-for-public

World Health Organization. 2020c. Coronavirus disease 2019 (COVID-19) Situation

World Health Organization. 2020d. Transmission of SARS-CoV-2: implications for infection prevention precautions. https://www.who.int/newsroom/commentaries/detail/transmission-of-sars-cov-2-implications-for-infection-preventionprecautions

Xing X, Guan X, Liu L, Zhan J, Jiang H, Liu L, Li G, Xiong J, Tan L, Xu J, Jiang Y, 95(4):e2533, doi:10.1097/MD.0000000000002533 (2016). SARS-CoV-2 in healthcare premises. Journal of Infection S0163-4453(20)30260-7. doi:10.1016/j.jinf.2020.04.034.

Yezli S, Otter JA. 2011. Minimum infective dose of the major human respiratory and enteric viruses transmitted through food and the environment. Food and Environmental Microbiology 3:1-30. secreted lipases against flaviviruses, SARS-CoV-2 and other enveloped viruses. bioR $R_{x} i v$ 2020.05.22.109900 doi: https://doi.org/10.1101/2020.05.22.109900 severe fever with thrombocytopenia syndrome virus in China. Virologica Sinica 32(1):51-62.

Zhang DX. 2020. SARS-CoV-2: air/aerosols and surfaces in laboratory and clinical settings. Journal of Hospital Infection 105:577-579.

Zhang Y, Chen C, Zhu S, Shu C, Wang D, Song J, Zhen W, Feng Z, Wu G, Xu J, Xu W. 2020. Notes from the field: Isolation of 2019-nCoV from a stool specimen of a laboratory-confirmed case of the coronavirus disease 2019 (COVID-19). Chinese Center for Disease Control Weekly 2(8):123-124.

Zhou P, Yang X-L, Wang X-G, Hu B, Zhang W, Si H-R, Zhu Y, Li B, Huang C-L, Chen H-D, Chen J, Luo Y, Guo H, Jiang R-D, Liu M-Q, Chen Y, Shen X-R, Wang X, Zheng X-S, Zhao K, Chen Q-J, Deng F, Liu L-L, Yan B, Zhan F-X, Wang Y-Y, Xiao G-F, Shi Z-L. 2020. A pneumonia outbreak associated with a new coronavirus of probable bat origin. Nature 579(7798):270-273. 
805

806

807

808

809

810

811

812

813

814

815

816

817

818

819

820

821
Zhu N, Zhang D, Wang W, Li X, Yang B, Song J, Zhao X, Huang B, Shi W, Lu R, Niu P, Zhan F, Ma X, Wang D, Xu W, Wu G, Gao GF, Tan W, China Novel Coronavirus Investigating and Research Team. 2020. A novel coronavirus from patients with pneumonia in China, 2019. The New England Journal of Medicine 382:727-733.

Zonta W, Mauroy A, Farnir F, Thiry E. 2016. Comparative virucidal efficacy of seven disinfectants against murine norovirus and feline calicivirus, surrogates of human norovirus. Food and Environmental Virology 8(1):1-12.

\section{Declarations}

\section{Acknowledgements}

We thank Dr. Chris Jones and Dr. Mark Ripley both from Reckitt Benckiser R\&D for their critical review of the manuscript and feedback. The authors gratefully acknowledge Jennifer Fairman for creating the illustrations in Fig. 1-3.

\section{Funding}

Funding for the preparation of this article was provided by Reckitt Benckiser LLC. 
822

823

824

825

826

827

828

829

830

831

832

833

834

835

836

837

838

\section{Authors' Contributions}

M.K.I, S.A.S, J.R.R, R.W.N., and C.P. Gerba contributed to data analysis and interpretation, preparation of the figures, and to authorship of the manuscript.

\section{Consent for publication}

Not applicable

\section{Availability of data and materials}

Not applicable.

\section{Competing Interests}

Joseph R. Rubino and M. Khalid Ijaz are employed by Reckitt Benckiser LLC, which provided funding for the preparation of the manuscript. The other authors have no financial interest in Reckitt Benckiser LLC. Raymond W. Nims is employed by RMC Pharmaceutical Solutions, Inc. and received a fee from Reckitt Benckiser LLC for his role in authoring and editing the manuscript. The other authors, M. Khalid Ijaz, Syed A. Sattar, Joseph R. Rubino, and Charles P. Gerba, declare no financial or non-financial conflicts of interest in this work. 


\section{Figure Legends:}

840 Figure 1 Modes of transmission of viruses, such as SARS-CoV, MERS-CoV, and SARS-

841 COV-2, emphasizing multi-system infections (modified from Otter et al., 2011).

842 Figure 2 Hierarchy of sensitivity of pathogens to formulated microbicidal actives (adapted

843 from Sattar (2007).

844 Figure 3 Ultrastructural differences between enveloped and non-enveloped viruses.

845 Conformationally, these viral genomes may be single-or double-stranded, and segmented or non-

846 segmented (examples are not shown in the figure). 


\section{Table $\mathbf{1}$ (on next page)}

Characteristics of selected emerging/re-emerging viruses including SARS-CoV-2.

Notes \pm , ambisense; -, negative sense; + , positive sense; ss, single-stranded. Segments (1) equates to a non-segmented genome. †Now referred to as Huaiyangshan banyangvirus. $¥$ Suspected primary host based on $>90 \%$ sequence homology to bat coronaviruses (Zhou et al., 2020). 


\begin{tabular}{|c|c|c|c|c|c|c|}
\hline Virus & Family & Particle size & $\begin{array}{l}\text { Lipid } \\
\text { envelope }\end{array}$ & $\begin{array}{l}\text { Genome* } \\
\text { (segments) }\end{array}$ & $\begin{array}{l}\text { Reservoir } \\
\text { species }\end{array}$ & References \\
\hline Lassa virus & Arenaviridae & $110-130 \mathrm{~nm}$ & yes & $\pm \operatorname{ssRNA}(2)$ & rodent & $\begin{array}{l}\text { Viral Hemorrhagic Fever Consortium, 2020; St. } \\
\text { Georgiev, } 2009\end{array}$ \\
\hline SFTSV $\uparrow$ & Phenuiviridae & $80-100 \mathrm{~nm}$ & yes & -ssRNA(3) & tick & Zhan et al., 2017 \\
\hline Hantaan virus & Hantaviridae & $80-120 \mathrm{~nm}$ & yes & -ssRNA(3) & rodent & $\begin{array}{l}\text { Jiang et al., 2016; Brocato and Hooper, 2019; } \\
\text { Laenen et al., } 2019\end{array}$ \\
\hline MERS-CoV & Coronaviridae & $118-136 \mathrm{~nm}$ & yes & $+\operatorname{ssRNA}(1)$ & bat & $\begin{array}{l}\text { Otter et al., 2011; MERS } 2013 \text {; Gorbalenya et } \\
\text { al., } 2020\end{array}$ \\
\hline SARS-CoV & Coronaviridae & $80-90 \mathrm{~nm}$ & yes & $+\operatorname{ssRNA}(1)$ & bat & $\begin{array}{l}\text { Otter et al., 2011; MERS } 2013 \text {; Gorbalenya et } \\
\text { al., } 2020\end{array}$ \\
\hline SARS-CoV-2 & Coronaviridae & $60-140 \mathrm{~nm}$ & yes & $+\operatorname{ssRNA}(1)$ & bat & $\begin{array}{l}\text { Munster et al., } 2020 \text {; Zhou et al., 2020; Zhu et } \\
\text { al., } 2020\end{array}$ \\
\hline Ebola virus & Filoviridae & $80 \times 14000 \mathrm{~nm}$ & yes & - ssRNA(1) & bat & St. Georgiev, 2009 \\
\hline Influenza H5N1 & Orthomyxoviridae & $80-120 \mathrm{~nm}$ & yes & $-\operatorname{ssRNA}(8)$ & avian & Cassidy et al., 2018 \\
\hline Nipah virus & Paramyxoviridae & $40-1900 \mathrm{~nm}$ & yes & -ssRNA(1) & bat & Ang et al., 2018 \\
\hline EV-D68 & Picornaviridae & $\sim 30 \mathrm{~nm}$ & no & $+\operatorname{ssRNA}(4)$ & unknown & Cassidy et al., 2018 ; Sun et al., 2019 \\
\hline
\end{tabular}

1

\section{Notes}

\pm , ambisense; -, negative sense; +, positive sense; ss, single-stranded. Segments (1) equates to a non-segmented genome. $\dagger$ Now referred to as Huaiyangshan banyangvirus. $\$$ Suspected primary host based on $>90 \%$ sequence homology to bat coronaviruses (Zhou et al., 2020). 


\section{Table 2 (on next page)}

Transmission and mortality of emerging/re-emerging viruses including SARS-CoV-2

Notes: "Contact" refers to contact with bodily fluids or with fomites; "aerosols/droplets" equates to respiratory aerosols/large or small droplets. CNS, central nervous system, GI, gastrointestinal 


\begin{tabular}{|c|c|c|c|c|}
\hline Virus & Tropism for organs & Mode of transmission & $\begin{array}{l}\text { Case } \\
\text { Mortality }\end{array}$ & Reference \\
\hline Lassa virus & Vascular system & Contact, aerosols/droplets & $15-20 \%$ & St. Georgiev, 2009; Cieslak et al., 2019 \\
\hline SFTSV & Vascular system & Vector (tick) & $12-30 \%$ & Xing et al., 2016 ; Zhan et al., 2017 \\
\hline Hantaan virus & Lower respiratory, renal & Contact, aerosols/droplets & $1-15 \%$ & $\begin{array}{l}\text { Nolte et al., 1995; St. Georgiev, 2009; Krüger } \\
\text { et al., } 2011 \text {; Jiang et al., } 2016\end{array}$ \\
\hline MERS-CoV & Lower respiratory, GI & Contact, aerosols/droplets & $34-36 \%$ & $\begin{array}{l}\text { Cieslak et al., 2019; Weber et al., 2019; } \\
\text { Paules et al., 2020; van Doremalen et al., } \\
2013\end{array}$ \\
\hline SARS-CoV & Lower respiratory & Contact, aerosols/droplets & $15 \pm 11 \%$ & Chan et al., 2011; Cieslak et al., 2019 \\
\hline SARS-CoV-2 & Lower respiratory, GI & Contact, aerosols/droplets & $4 \%$ & $\begin{array}{l}\text { WHO, 2020c; Morawska et al., 2020; Zhang } \\
\text { et al., } 2020\end{array}$ \\
\hline Ebola virus & Vascular system & Contact, aerosols/droplets & $41 \%$ & $\begin{array}{l}\text { Fischer et al., } 2015 \text {; Cieslak et al., 2019; } \\
\text { Weber et al., } 2019\end{array}$ \\
\hline Influenza H5N1 & Upper respiratory & Contact, aerosols/droplets & $>60 \%$ & U.S. CDC, 2015; Cieslak et al., 2019 \\
\hline Nipah virus & CNS, respiratory & Contact, ingestion & $65 \pm 28 \%$ & Ang et al., 2018; Hassan et al., 2018 \\
\hline EV-D68 & Respiratory, CNS & aerosols/droplets, contact & Up to $10 \%$ & Oermann et al., 2015; Cassidy et al., 2018; \\
\hline
\end{tabular}

2 Notes:

3 "Contact" refers to contact with bodily fluids or with fomites; "aerosols/droplets" equates to respiratory aerosols/large or small 4 droplets. CNS, central nervous system, GI, gastrointestinal 


\section{Table 3 (on next page)}

Environmental survival of emerging/re-emerging viruses including SARS-CoV-2 under ambient conditions.

Notes: †No data for SFTSV are available, the result displayed is for Crimean-Congo virus. *Aerosol data for human coronavirus 229E (Ijaz et al., 1985). Survival half-life depended on humidity and temperature. The values ranged from $3.3 \mathrm{~h}(\sim 80 \% \mathrm{RH}), 67 \mathrm{~h}(50 \% \mathrm{RH})$, to $27 \mathrm{~h}$ (30\% RH). $¥$ No data for EV-D68 are available; the result displayed is for human rhinovirus type 14 at 15-55\% RH (Sattar et al., 1987). IThe authors only evaluated times up to $3 \mathrm{~h}$ (van Doremalen et al., 2020). 


\begin{tabular}{|c|c|c|c|}
\hline Virus & Survival on surfaces & $\begin{array}{l}\text { Survival in } \\
\text { aerosols }\end{array}$ & Reference \\
\hline Lassa virus & $0.41 \log _{10} / \mathrm{d}$ (glass) & $\mathrm{t} 1 / 2=0.62 \mathrm{~h}$ & $\begin{array}{l}\text { Stephenson et al., 1984; Sagripanti et } \\
\text { al., } 2010\end{array}$ \\
\hline SFTSV & $\mathrm{t}^{1} / 2=0.75 \mathrm{~h}($ aluminum $) \dagger$ & No data & Hardestam et al., 2007 \\
\hline Hantaan virus & $\mathrm{t}^{1} / 2=1.0 \mathrm{~h}$ (aluminum) & No data & Hardestam et al., 2007 \\
\hline MERS-CoV & $\mathrm{t}^{1} / 2=0.94 \mathrm{~h}($ steel $)$ & $\mathrm{t}^{1} / 2=27 \mathrm{~h} *$ & $\begin{array}{l}\text { Ijaz et al., 1985; van Doremalen et } \\
\text { al., } 2013\end{array}$ \\
\hline SARS-CoV & $\mathrm{t}^{1} / 2=10 \mathrm{~h}($ steel $), 18 \mathrm{~h}$ (plastic) & $\begin{array}{l}\text { At least } 3 \mathrm{~h} \\
\mathrm{t}^{1} / 2=27 \mathrm{~h}^{*}\end{array}$ & $\begin{array}{l}\text { Ijaz et al., 1985; Chan et al., 2011; } \\
\text { van Doremalen et al., } 2020\end{array}$ \\
\hline SARS-CoV-2 & $\begin{array}{l}\mathrm{t}^{1} / 2=5 \text { min (cloth), } 13-14 \mathrm{~h} \text { (steel), } 16 \mathrm{~h} \text { (plastic), } \\
19 \mathrm{~h} \text { (mask), } 4 \mathrm{~h} \text { (swine skin) }\end{array}$ & $\begin{array}{l}\text { At least } 3 \mathrm{~h}- \\
\mathrm{t}^{1} / 2=27 \mathrm{~h}^{*}\end{array}$ & $\begin{array}{l}\text { Ijaz et al., 1985; Chin et al., 2020; } \\
\text { van Doremalen et al., } 2020 \text {; } \\
\text { Harbourt et al., } 2020\end{array}$ \\
\hline Ebola virus & $\begin{array}{l}0.68 \log _{10} / \mathrm{d} \text { (glass) } \\
0.88 \log _{10} / \mathrm{d} \text { (steel) }\end{array}$ & $\mathrm{t}^{1} / 2=0.25 \mathrm{~h}$ & $\begin{array}{l}\text { Cook et al., 2015; Fischer et al., } \\
\text { 2015; Sagripanti et al., 2010; Piercy } \\
\text { et al., } 2010\end{array}$ \\
\hline Influenza H5N1 & $<1 \mathrm{~d}$ (glass, metal) & No data & Wood et al., 2010 \\
\hline Nipah virus & $1 \mathrm{~h}$ (plastic) & No data & US EPA, 2014 \\
\hline EV-D68 & $\mathrm{t}^{1} / 2=0.17$ to $0.25 \mathrm{~h}($ steel $) t$ & No data & Sattar et al., 1987 \\
\hline
\end{tabular}

1

$\uparrow$ No data for SFTSV are available; the result displayed is for Crimean-Congo virus.

*Aerosol data for human coronavirus 229E (Ijaz et al., 1985). Survival half-life depended on humidity and temperature. The values ranged from $3.3 \mathrm{~h}(\sim 80 \% \mathrm{RH}), 67 \mathrm{~h}(50 \% \mathrm{RH})$, to $27 \mathrm{~h}(30 \% \mathrm{RH})$. 
5 \$No data for EV-D68 are available; the result displayed is for human rhinovirus type 14 at 15-55\% RH (Sattar et al., 1987).

6 TThe authors only evaluated times up to $3 \mathrm{~h}$ (van Doremalen et al., 2020). 
Figure 1

Modes of transmission of viruses, emphasizing multi-system infections such as SARSCoV, MERS-CoV, and SARS-COV-2 (modified from Otter et al., 2011).

(c) 2020, Fairman Studios, LLC. CC BY 4.0.

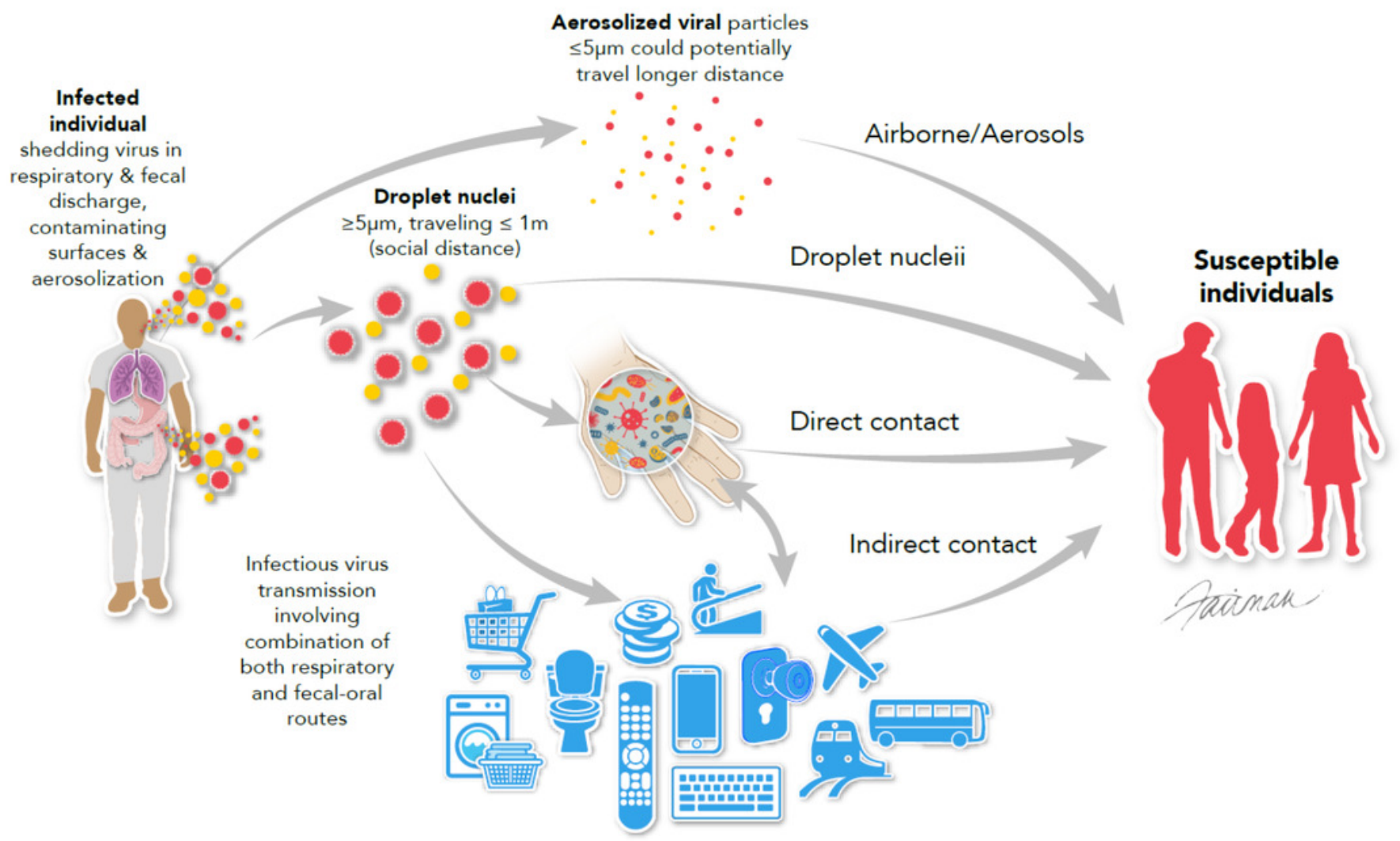


Figure 2

Hierarchy of sensitivity of pathogens to formulated chemical microbicides (adapted from Sattar (2007)).

(c) 2020, Fairman Studios, LLC. CC BY 4.0.

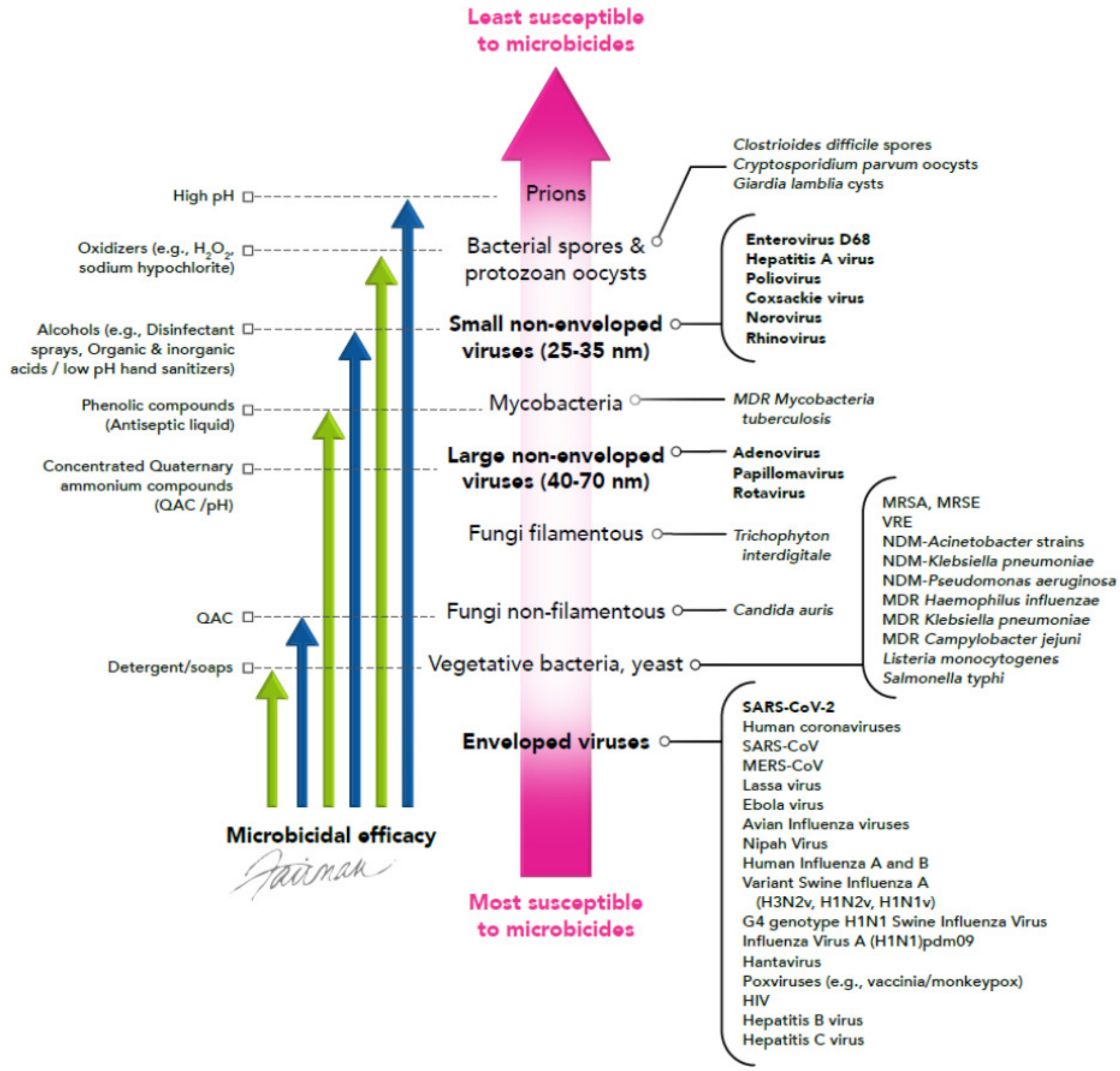


Figure 3

Ultrastructural differences between enveloped and non-enveloped viruses.

Genotypically, these viral genomes may be single-or double-stranded, and segmented or non-segmented (examples are not shown in the figure).

(c) 2020, Fairman Studios, LLC. CC BY 4.0.

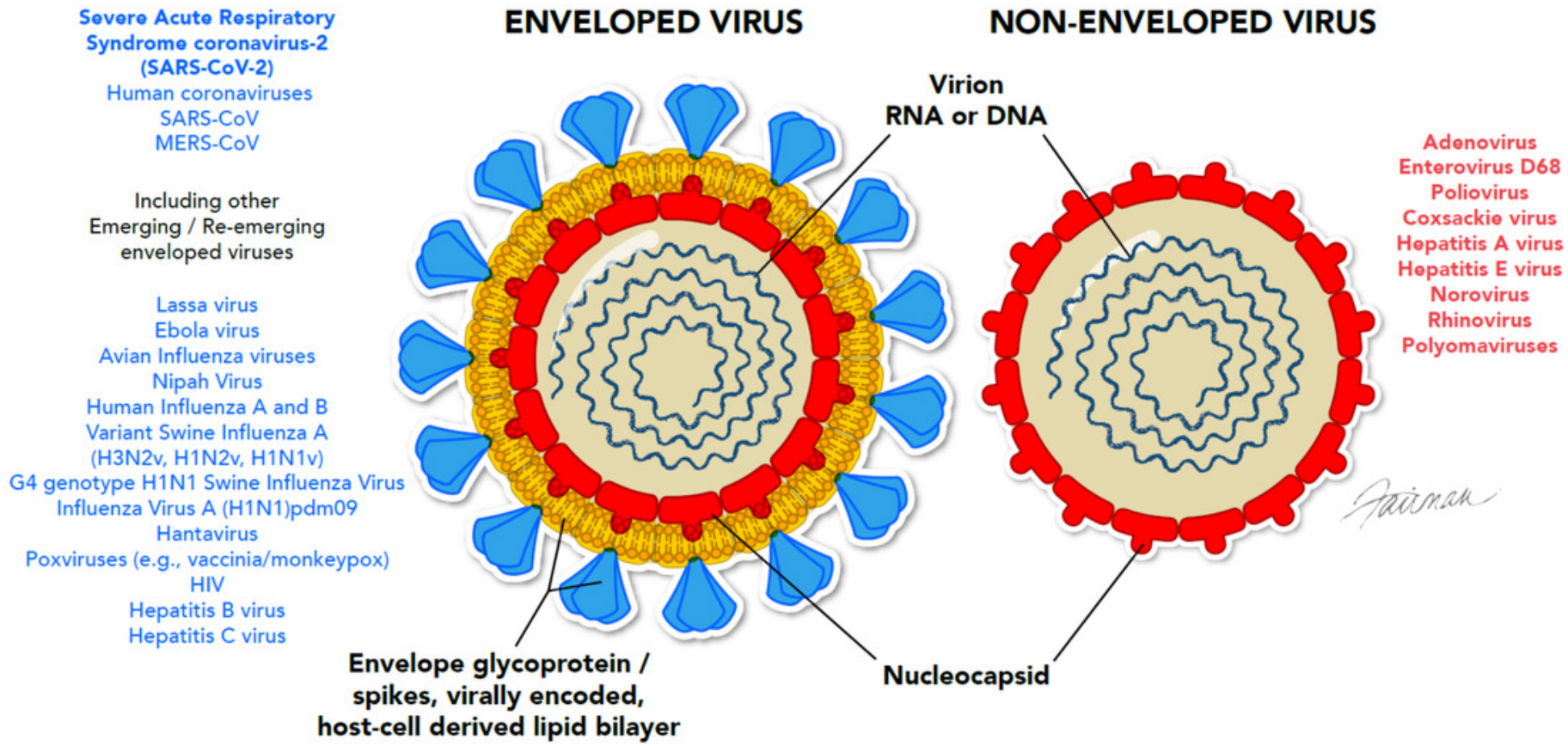

